\title{
Special
Series
}

\section{Advancing Wireless Sensor Networks for Irrigation Management of Ornamental Crops: An Overview}

\author{
John D. Lea-Cox ${ }^{1,9}$, William L. Bauerle ${ }^{2}$, Marc W. van Iersel $^{3}$, \\ George F. Kantor ${ }^{4}$, Taryn L. Bauerle ${ }^{5}$, Erik Lichtenberg ${ }^{6}$, \\ Dennis M. King ${ }^{7}$, and Lauren Crawford ${ }^{8}$
}

AdDITIONAL INDEX wORDs. greenhouse, modeling, nursery, private benefits, public benefits, soil moisture sensor

SUMmARY. Wireless sensor networks (WSNs) transmit sensor data and control signals over long distances without the need for expensive infrastructure, allowing WSNs to add value to existing irrigation systems since they provide the grower with direct feedback on the water needs of the crop. We implemented WSNs in nine commercial horticulture operations. We provide an overview of the integration of sensors with hardware and software to form WSNs that can monitor and control irrigation water applications based on one of two approaches: 1) "set-point control" based on substrate moisture measurements or 2) "model-based control" that applied species-specific irrigation in response to transpiration estimates. We summarize the economic benefits, current and future challenges, and support issues we currently face for scaling WSNs to entire production sites. The series of papers that follow either directly describe or refer the reader to descriptions of the findings we have made to date. Together, they illustrate that WSNs have been successfully implemented in horticultural operations to greatly reduce water use, with direct economic benefits to growers.

A gricultural irrigation consumes about $69 \%$ of available freshwater resources worldwide (Fry, $2005)$. In the United States, irrigation accounts for $62 \%$ of freshwater, including $68 \%$ of groundwater and $29 \%$ of surface water withdrawals (excluding water use for thermoelectric) (Kenny et al., 2009). Major concerns loom about future global freshwater resources due to the effects of climate change on rainfall patterns, annual snowpack, drought and flood events, as well as changes in water quality (Arndt et al., 2013). During the past 50 years, the demand for freshwater in the United States has increased (Hutson et al., 2004), whereas the quality of both surface and groundwater has declined due to pollution from both point and nonpoint sources (Secchi et al., 2007). Global population in the 20th century increased by a factor of three, while water withdrawals increased by a factor of seven during the same time, with little hope of these rates slowing in the near future (Agarwal et al., 2000). Thus, as the public demands on water supplies increase, freshwater availability for agriculture will likely decrease. For individual growers, these changes could lead to a revision of water rights in western U.S. states and the need for more efficient water use throughout the United States. Overall, the future holds the promise of more restrictive regulation of water use, whether from surface or groundwater sources, with additional scrutiny on maintaining water quality.

In light of increased competition for water resources, there is a clear need to increase our irrigation efficiency to ensure national and global food security (U.S. Agency for International Development, 2013). To achieve this, crop water use information is essential. Most farmers do not know the water requirements of the crops they grow at any level of precision because soil type, water-holding capacity, and their local environmental conditions constantly interact to make crop water use dynamic. Efficient water management is typically not a priority in developed countries, since the cost of water is low in proportion to other production costs. Hence, there have been few incentives for growers to consider using irrigation water efficiently. Consequently, the amount of irrigation water applied is largely based upon availability, rather than actual crop water needs (Balendonck et al., 2009).

The development of precision (low-volume) irrigation systems has played a major role in reducing the water applied to high-value crops. However, the need to optimize crop yield has increased the necessity for new methods to achieve accurate irrigation scheduling and control (Jones, 2008). For high-value horticultural crops, there is significant interest in using decision irrigation (i.e., irrigating based on decision criteria such as soil moisture content) to precisely apply water while improving crop yield, reducing nutrient loss and disease pressure. Therefore, achievement of optimal irrigation will depend not only on the use of precision irrigation systems, but also on easy-to-use decision

\begin{tabular}{llll}
\hline $\begin{array}{l}\text { Units } \\
\begin{array}{l}\text { To convert U.S. to SI, } \\
\text { multiply by }\end{array}\end{array}$ & U.S. unit & SI unit & $\begin{array}{l}\text { To convert SI to U.S., } \\
\text { multiply by }\end{array}$ \\
\hline 0.9072 & ton(s) & $\mathrm{Mg}$ & 1.1023
\end{tabular}


tools that help the farmer monitor and automate irrigation scheduling.

WHY DO HORTICULTURAL CROPS REQUIRE DIFFERENT IRRIGATION STRATEGIES AS COMPARED WITH AGRONOMIC CROPS? Wireless sensor networks have been used for a variety of applications (Akyildiz et al., 2002), including more efficient irrigation (McCullogh et al., 2008). However, WSNs developed for agricultural applications may not be appropriate for horticulture. The primary reason that horticultural crops require a different approach to irrigation management, compared with traditional row crop agriculture, is due to three basic factors: 1) large variation in production methods, 2) large number of species grown, with substantial variations in water use among species, and 3 ) within-site spatial and temporal variability in crop water use and irrigation water supply. In addition, the cost of irrigation water is often perceived as only a small fraction of total production costs while the value of horticultural products is high. Therefore, the risk of decreased yield deters reductions in water use. However, many growers underestimate the costs of excessive irrigation at the farm and society level. Our group is addressing the issues surrounding the diversity of crop water use and the complexity of irrigation management, as well as the economic impact on individual businesses and society.

\footnotetext{
This paper is part of a series of manuscripts describing the research and development completed by the SCRI-MINDS (Managing Irrigation and Nutrition through Distributed Sensing) project. The authors gratefully acknowledge funding and support from the USDA-NIFA Specialty Crops Research Initiative; Award \#2009-51181-05768.

${ }^{1}$ Department of Plant Science and Landscape Architecture, University of Maryland, 2120 Plant Sciences Building, College Park, MD 20742

${ }^{2}$ Department of Horticulture and Landscape Architecture, Colorado State University, Fort Collins, CO 80523

${ }^{3}$ Department of Horticulture, University of Georgia, 1111 Miller Plant Science Building, Athens, GA 30602

${ }^{4}$ Carnegie Mellon University, Robotics Institute, 5000 Forbes Avenue, Pittsburgh, PA 15213

${ }^{5}$ Department of Horticulture, Cornell University, 134A Plant Sciences Building, Ithaca, NY 14853

${ }^{6}$ Department of Agricultural and Resource Economics, University of Maryland, 2102 Symons Hall, College Park, MD 20742

${ }^{7}$ University of Maryland Center for Environmental Science, Chesapeake Biological Laboratory, Solomons, MD 20688

${ }^{8}$ Decagon Devices, Inc., 2365 Northeast Hopkins Court, Pullman, WA 99163

${ }^{9}$ Corresponding author. E-mail: jlc@umd.edu.
}

The majority of ornamental crops in the United States are now grown in container-nurseries and greenhouses using soilless substrates (U.S. Department of Agriculture, 2004, 2009). Excessive irrigation readily leaches nutrients from soilless substrates (Ristvey et al., 2004). Preventing unwanted leaching requires precise applications of irrigation water. Hence, irrigation and nutrient management are inseparable issues for greenhouses and nurseries (Ross et al., 2001). By providing better plant water use information, we can improve the efficiency of water and nutrient use by limiting leaching and runoff (Warsaw et al., 2009).

Irrigation management is challenging given the large number of species that are grown in field, container-nursery, and greenhouse operations (Majsztrik et al., 2011), resulting in diverse water requirements that are often delivered with different irrigation systems (i.e., overhead, microsprinkler, and drip emitters). Additionally, large acreages of field-grown (soil) trees whose water needs are analogous to orchards have more expansive rooting volumes, making irrigation water requirements even harder to estimate. Ornamental production systems, therefore, do not typically lend themselves to water management techniques developed for agronomic systems (e.g., twodimensional process model transpiration estimates, uniform center pivot irrigation).

Perhaps most importantly, temporal scales of water use in intensive plant production operations are on the order of hours (i.e., roots in a container can use the available water in a very short time) compared with the daily to weekly irrigation intervals of soil production systems. Moreover, many greenhouse and nursery growers base their irrigation scheduling decisions on intuition or experience (Bacci et al., 2008; Jones, 2008). Belayneh et al. (2013) point out that growers often make incorrect decisions about irrigation scheduling, mentioning how surprising it is that many "advanced" irrigation scheduling systems automate irrigation cycles only on the basis of time, without any feedback mechanisms. Thus, even with advanced time-based systems, the decision to irrigate is usually based solely on the operator's judgment of crop water use or weather conditions.
Approaches to irrigation scheduling using current techniques have been the subject of many reviews including measuring soil moisture (e.g., Bitelli, 2011; Dane and Topp, 2002; Pardossi et al., 2009), physiological measurements (e.g., Cifre et al., 2005; Jones, 2004), or water balance calculations (e.g., Allen et al., 1989). Lea-Cox (2012) provides a recent review for using WSNs for precision irrigation scheduling. A conventional sensor-based approach typically provides information to schedule irrigation events based on soil moisture content, either through direct measurements with capacitance or time domain reflectometry-type sensors (Smith and Mullins, 2001; Topp, 1985), tensiometers (Hansen and Pasian, 1999; Lieth and Burger, 1989; Smajstrla and Harrison, 1998), or soilmoisture water balance calculated from daily evapotranspiration $\left(\mathrm{E}_{\mathrm{T}}\right)$ estimates (Allen et al., 1989). In addition, automated greenhouse systems have used load cells for the estimation of daily plant water use (Raviv et al., 2000). If operated correctly, most of these systems can enable greater precision and improved water use efficiency over traditional time-based irrigation scheduling methods (e.g., Belayneh et al., 2013). Although these sensor technologies have been tried over the years (most recently reviewed by van Iersel et al. (2013), none have gained wide-scale acceptance in a commercial nursery production setting. Currently, irrigation technology has advanced to a stage that the debate now centers around the practicality and economics of using direct soil moisture sensing, plant water use estimates, or a combination of the two.

\section{Project scope and vision}

We established a comprehensive list of objectives to guide the development of WSN tools and strategies, accounting for "ideal" features for intensive horticultural production irrigation scheduling systems (Lea-Cox et al., 2008). Jones (2008) noted that any system should be l) sensitive to small changes, whether in terms of soil moisture content, evaporative demand, or plant response; 2) able to respond in real time, allowing for continual monitoring and maintenance of optimal water status with changing weather conditions; 3 ) readily adaptable to different crops, growth 
stages and environments without the need for extensive modification; 4) robust and reliable; 5 ) user-friendly, requiring little user training; 6) capable of automation, thus reducing labor requirements; and 7) low cost, both in terms of purchase price and maintenance costs.

In addition to the overarching irrigation control requirements, our group defined a number of additional WSN requirements, where 1) users should be able to rapidly deploy sensors in any production area to maximize utility and minimize cost; 2) WSNs should be scalable, thereby allowing an operation to begin with a small, low-cost system and expand/ improve the network over time; 3) nodes (motes) should have low power (battery) requirements, preferably with rechargeable power options; 4) sensor data should be reliably transmitted with little or no interference over at least $1000 \mathrm{~m} ; 5$ ) the software interface should automatically log and display real-time data, in an easily interpreted form, preferably as a customizable graphical output; 6) any software control functions should include relatively sophisticated decision tools and discretionary options to allow for maximum flexibility in scheduling/ actuating irrigation solenoids or other control devices (Lea-Cox et al., 2008).

In turn, these engineering objectives were the foundation for our scientific, implementation and socioeconomic objectives (Lea-Cox et al., 2010) to: 1) fulfill the monitoring and control requirements for all ornamental production systems; 2 ) determine the performance, variability, and utility of soil moisture and electrical conductivity sensors to minimize the sensors required for precision irrigation and nutrient management at various scales; 3) integrate various environmental sensors into WSNs to enable real-time modeling of plant evapotranspiration; 4) integrate soil and environmental data into speciesspecific models; 5) develop best management practices for the use of sensors; 6) quantify improvements in water and nutrient management and runoff, plant quality, and yield; 7) evaluate the private and public economic and environmental impacts of precision sensorcontrolled practices; 8) identify barriers to adoption and implementation of these practices; and 9) engage growers and the industry.

As part of the project, we are identifying the costs and benefits of WSN technology to the industry and society, including barriers to adoption. We are working across various scales of production using small and large commercial farms $(<\$ 100,000$ and $>\$ 1$ million annual net income, respectively) and taking a systems approach to define the hardware and software required to satisfy our project objectives (Fig. 1). There are many parallels between our project and the needs of the fruit and nut production industry, as well as field and greenhouse vegetable production, so we expect that our results may ultimately benefit a large portion of the horticultural industry. The project has directly involved commercial growers throughout the development process,

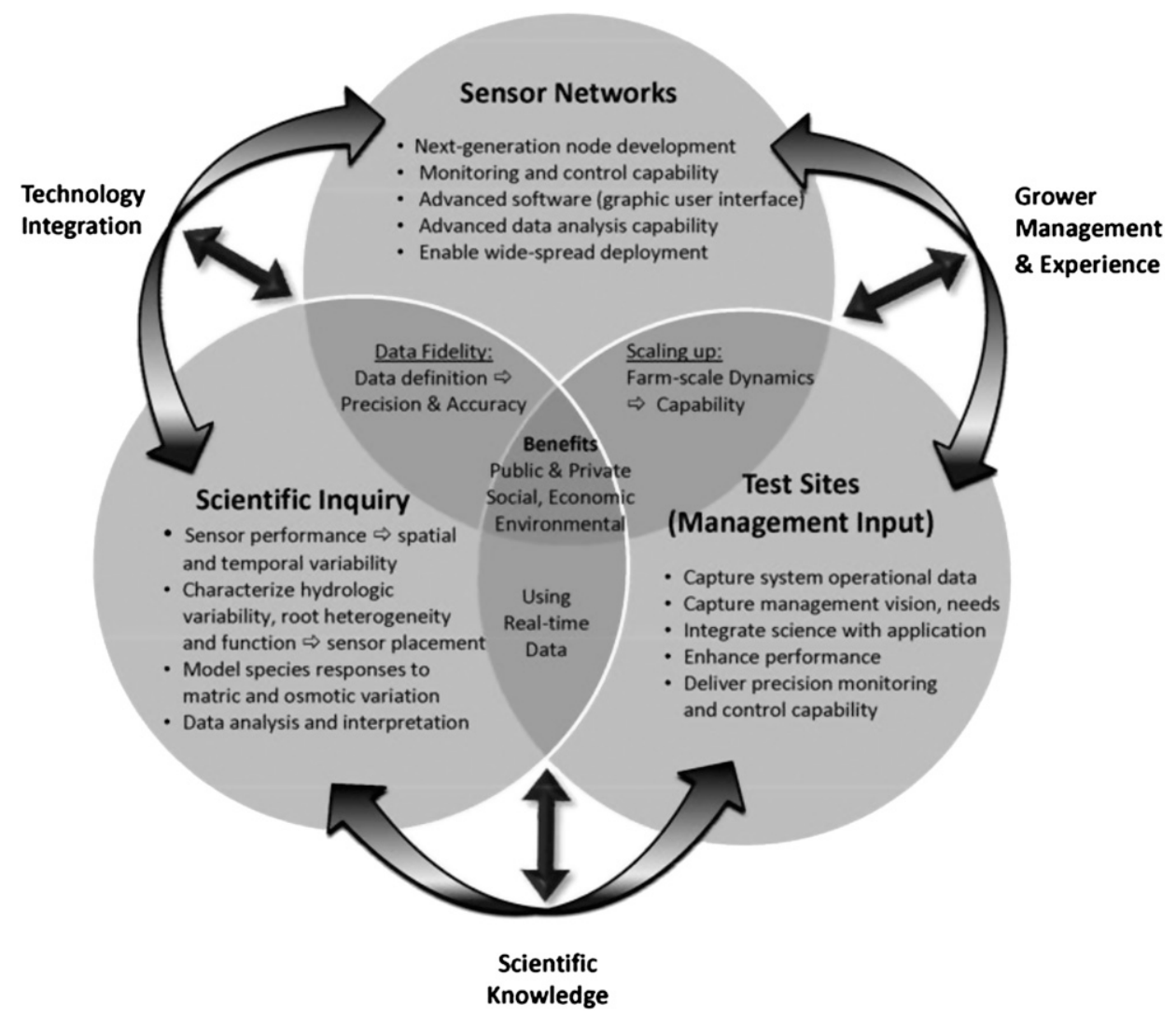

Fig. 1. Integration of project goals and major activities. The engineering team developed sensor networks, both hardware and software, which were subsequently used to meet the scientific objectives of the project and tested in commercial greenhouses and nurseries to assure that the networks met the needs of the industry. Research results were used to guide on-farm irrigation management, while on-farm experiences were used to guide the research. Our findings were then integrated to determine the public and private (farm-level) benefits of the sensor networks. 
using deployments in commercial operations as test sites. Each farm and research test site is equipped with a sensor network to provide real-time environmental data for scientific and technological development. Data streams are monitored on a day-today basis by growers, engineers and scientists, which drives a daily dialogue between growers and researchers. This iterative process is vital for ensuring the development and successful implementation of the next generation of sensor networks.

\section{Interdisciplinary teams and partners}

ENGINEERING: HARDWARE AND SOFTWARE DEVELOPMENT. The primary role of the engineering team is to develop advanced WSN capabilities, as discussed by Kohanbash et al. (2013). We have developed a hardware and software platform that integrates both the direct sensing of substrate volumetric water content and the use of set-point (threshold) control for automating irrigation decisions with a model-based approach that estimates plant water use through measurements of transpiring leaf surface area, canopy volume, and physiological leaf parameters, combined with real-time environmental measurements (Barnard and Bauerle, 2013). Kohanbash et al. (2013) illustrates how this hardware and software integrates into actionable information that allows sensor nodes to make reliable irrigation decisions.

Sensorweb software (Kohanbash et al., 2011) provides many advanced user controls, in addition to providing data filtering and analysis that is not seen by the end user. The software refines incoming data and provides an easy-to-use web-based program to visualize the WSN information and schedule irrigation events based on either user preference or automatic (set-point) control. This system provides growers with four irrigation modes detailed in Kohanbash et al. (2013). In brief, the grower specifies irrigation parameters that can be entered into the software using a graphical user interface. These settings then allow the WSN to implement this grower-defined strategy. The interaction of these hardware and software capabilities allows for very precise application of irrigation water, as illustrated by Belayneh et al. (2013).
SCIENTIFIC ENQUIRY: ENABLING ACTIONABLE DECISIONS. We are focused on research objectives that bridge various scales of production for specialty crops. Understanding the spatial variability of environmental data are one of the most important aspects of deploying WSNs to allow for better sensor placement. This in turn maximizes precision and return on investment (van Iersel et al., 2013). Characterizing sensor performance and precision is also essential to match the right sensor with the right situation. Lastly, we ensure that irrigation scheduling decisions made (either manually or automatically) are commensurate with plant water requirements in real time, while placing a minimum burden on the grower managing the system. Applying these findings to both field- and containergrown species would greatly increase our understanding of correct sensor placement in root zones, increasing the precision of information for controlling irrigation events. However, since root distribution is affected by irrigation method, optimal placement of soil moisture sensors for irrigation control may depend on how the crop is irrigated (van Iersel et al., 2011).

Bauerle et al. (2013a) explore issues related to root distribution and the spatial variability of substrate moisture content within containers. Of the tree species studied, they found two patterns of root distribution with a subset of species developing a shallow "conical-shaped" root system and a second subset developing a more evenly distributed "cylindrical" root system. Conical root systems (i.e., those with the broadest portion of the root system in the shallow substrate layer) had lower substrate moisture variability, while the opposite was true for cylindrical root systems that accessed a larger portion of the shallower and central layers of the container. Additionally, van Iersel et al. (2013) show that sensor variability also depends on substrate moisture content, with the greatest variability seen at moisture contents just below the water-holding capacity of the substrate.

\section{Approaches}

In this project, the scientific team has used two different approaches to precision irrigation; i.e., set-point control (using soil moisture sensor readings to trigger irrigation) and model-based control (using crop and environmental data to predict crop water use).

SET-POINT CONTROL. van Iersel and his group have shown that automated irrigation using soil moisture sensors can be used to maintain very precise irrigation of greenhouse crops in soilless substrates (Burnett and van Iersel, 2008; Kim and van Iersel, 2009; Nemali and van Iersel, 2006; van Iersel et al., 2009, 2010, 2011). In addition, they maintained very precise low substrate moisture contents, advancing our ability to use precision irrigation scheduling for regulated deficit irrigation (Jones, 2004). This can increase fruit crop quality (Fereres et al., 2003), aiding precision nutrient (Ristvey et al., 2004) and disease management (Lea-Cox et al., 2006). With the new nR5 control nodes developed by our project (Kohanbash et al., 2013), we have now scaled up our capability to use wide-area sensor networks in commercial operations (Chappell et al., 2013) and documented some economic impacts (Belayneh et al., 2013; Lichtenberg et al., 2013).

MODEL-BASEd CONTROL. Plant water use (transpiration) is a key process in the hydrologic cycle. Therefore, models that can accurately predict transpiration have important applications for irrigation scheduling and predicting crop yield. Modelbased water budget calculations are relatively easy to use for scheduling irrigation, since algorithms exist to calculate evapotranspiration (typically using the Penman-Monteith equation) that can use local meteorological or pan evaporation data (Fereres et al., 2003). This approach works well for agronomic and closed canopy horticultural crops, but is difficult to implement in open canopy ornamentals that lack known crop-specific physiology and morphology characteristics (Bauerle et al., 2002).

Our scientific modeling groups (Bauerle and Bowden, 201 la; Starry, 2013; van Iersel et al., 2010) have developed and validated models for diverse growing environments (e.g., nursery, greenhouse, green roof), which form the basis of the speciesspecific software. This enables predictive feed-forward management of water use with plant and environmental water-use models. Kim et al. (2011) demonstrated that the measured daily plant evapotranspiration of petunia 
(Petunia $\times$ bybrida) can be precisely modeled in greenhouse production with measurements of crop growth (days after planting, daily light integral, vapor pressure deficit, and air temperature). Kim and van Iersel's empirical modeling approach demonstrates the sensitivity of plant water use to these four easily measured variables. Thus, with a few inexpensive sensors (temperature, relative humidity, andphotosynthetic photon flux) and some simple software tools that integrate these variables on short time scales, it is now possible to accurately predict short-term plant water use for greenhouse crops. Nevertheless, these models still require rigorous validation for site-specific production conditions.

Increased complexity of predictive water use models is required to ensure functionality in outdoor production environments. For example, water use by perennial woody crop species is much more complicated because of dynamic water vapor conductance (e.g., leaf size variation among species), which results in different boundary layers and leaf temperatures in response to wind speed (Bauerle and Bowden, 2011b). However, Bowden et al. (2005) outlined an automated sensor-based irrigation system for nurseries that can calculate plant water consumption from species and genotype-specific plant morphological and physiological characteristics, using the multiarray evaporation stand tree radiation A (MAESTRA) model (Wang and Jarvis, 1990). MAESTRA is a three-dimensional process-based model that computes transpiration, photosynthesis, and absorbed radiation within individual tree crowns at relatively short (15-min) time intervals. The model is described more fully by Bauerle and Bowden (2011a) and has been modified and validated to estimate deciduous tree transpiration (Bauerle et al., 2002; Bowden and Bauerle, 2008; Reynolds et al., 2009) and withincrown light interception (Bauerle et al., 2004). The model applies physiological equations to subvolumes of the tree crown and then sums and/or averages the values for entire canopies. Additionally, species-specific physiological values can be incorporated into model calculations, yielding more robust estimates of whole tree transpiration for a variety of species. The model holds potential advantages for nursery, forest, and orchard water use prediction in that species-specific physiological and morphological parameters can be specified.

ECONOMIC BENEFITS. Using WSNs to manage irrigation can increase profitability by saving irrigation water, reducing the energy needed to pump water, the labor needed to operate the irrigation system, and time spent managing the irrigation system (Belayneh et al., 2013). Moreover, by reducing leaching, WSN-based irrigation can increase profits by reducing fertilizer expenditures. Other potential benefits of WSN-based systems are less obvious. Greater precision in maintaining soil moisture at desired levels can lower disease pressure, which is often caused by precautionary overwatering, lowering crop losses and expenditures on fungicides (Chappell et al., 2013; Lichtenberg et al., 2013). Better coupling of water availability to plant water uptake has also accelerated growth in some instances (Chappell et al., 2013). Shorter production times have resulted in higher profits because they lower inventory costs and optimize the use of production area (Lichtenberg et al., 2013).

WSN-based systems substitute capital for water and associated variable inputs like energy, labor, and fertilizer (Shani et al., 2009). Benefits and costs accrue at different points in time, with investment in sensor systems made up front and reductions in water costs, energy, labor, fertilizer, and pesticides realized later on. Annualizing revenues and expenditures adjusts for those differences in timing.

We used results from experiments on a shrub species, gardenia (Gardenia jasminoides) and two tree species, dogwood (Cornus florida 'Cherokee Brave') and red maple (Acer rubrum 'Red Sunset') to assess the potential profitability of WSNbased irrigation management. WSN irrigation management cut both the production time and crop losses of 'Heaven Scent' gardenia roughly in half and reduced the need for fungicide (Chappell et al., 2013); as a result, projected annual profit was $156 \%$ higher, primarily due to the reduction in production time (Lichtenberg et al., 2013). In tree production (Belayneh et al., 2013), no changes in growth rates occurred, but installation of a WSN to manage irrigation was projected to increase profits by $38 \%$ by reducing management time and pumping costs. Although water is inexpensive in some operations, the rate of return on investment for a WSN could see return rates 10-20 times higher in locations where water is more expensive (Belayneh et al., 2013).

\section{Current and future challenges}

SCALING UP. WSNs permit a grower to initially purchase a small network and later add nodes and sensors. Expansion of the WSN allows one to monitor and control irrigation over larger areas, potentially scaling up to an entire production site. Alternatively, growers can move sensors and nodes quickly as "nimble networks" within the production area, e.g., to address the water requirements of a specific indicator species or for specific diagnostic needs, e.g., for disease management in a crop (Lea-Cox et al., 2006). This nimble network approach is one of the most powerful ways to realize a quick return on WSN investment. In fact, we believe that there are many situations where a grower could recuperate WSN investment costs within 1 year.

However, challenges remain in scaling up WSNs to entire nursery or greenhouse operations due to the number of nodes and sensors that might be needed and the associated maintenance needs of the system. Given the broad array of species in many ornamental operations, it may be impractical to sense the soil moisture content of all crops on a site with a direct sensing approach; the variety of crops and container and plant sizes is simply too large. However, indicator species (i.e., species that have high or low water use) can inform irrigation schedules for plants of similar water use (Yeager et al., 2007). For this reason, we are developing crop models that include indicator species in the decision support software.

To do so, realistic descriptions of species-specific stomatal responses to environmental drivers can be used to accurately estimate irrigation requirements. Most physiology-based models for predicting plant water use (e.g., MAESTRA) describe stomatal conductance $\left(g_{S}\right)$ through a form of the Ball-Berry model (Ball et al., 1987). Among existing models, however, the parameterization of $g_{s}$, and therefore 
transpiration, varies widely due to the range in physiological values among species (Bauerle et al., 2013b). Different values for physiological parameters translate into different water use rates, making accurate parameterization essential for species and/or genotype specific water use estimates. At the same time, the array of physiological variation among the many ornamental species within a nursery/ greenhouse makes model parameterization challenging. Thus, physiologybased model application across an entire commercial horticultural production site has, so far, not been brought to fruition.

Similar to evapotranspiration equations (e.g., Penman-Monteith) that apply a crop coefficient to adjust potential evaporation to a crop-specific transpiration, physiology parameters in $g_{s}$ models allow for species-specific transpiration rate predictions. However, unlike the production of monoculture agronomic crops that use a single crop coefficient or physiology parameter set to represent a crop over hundreds of acres [e.g., corn (Zea mays)], ornamental production sites are faced with variation in species physiology, morphology, and canopy transpirational surface area at the subacre scale. To estimate irrigation requirements per species for the whole site, this situation requires more than a few crop coefficients and/or physiology parameter values (Barnard and Bauerle, 2013). Moreover, speciesspecific physiology and morphology fluctuate over the growing season, changing transpiration rates (e.g., Bauerle et al., 2012; Reynolds et al., 2009). These disparities from single species production complicate our ability to scale irrigation estimates in horticultural operations. Thus, there remains a need to understand how the choice of parameter values used in $g_{\mathrm{s}}$-based models impacts water fluxes among species physiology and morphology and how to account for variation in climate and physiology functional type (PFT) at the scale of an entire horticultural production site (Bauerle et al., 2013b). Through the research conducted in our project to date, we are now positioned to develop a physiologically based scaling process that allows us to predict and schedule PFT irrigation across an entire production site (e.g., a 500-acre nursery that contains hundreds of species).
An alternative to the PFT scaling approach is the use of remote sensing. Beeson (2012) showed that evapotranspiration estimates can be used to estimate the water requirements of ornamental plants, if those data are coupled with canopy closure data. Canopy closure typically has been difficult to measure for growers, but the recent release of a new normalized difference vegetation index (NDVI) sensor (Decagon Devices, Pullman, WA) allows for NDVI integration into WSNs. Wireless networks that offer the possibility of learning from automated data analysis (i.e., selfhealing systems) also provide exciting new possibilities for scaling up; the WSN could monitor crop characteristics, environmental conditions, and irrigation applications to "learn" how to optimally irrigate different crops. After the learning process is completed, the WSN could then implement the resulting irrigation strategy.

Adoption of THE TECHNOLOGY. Demonstration project results show that WSN-based irrigation management reduces water and energy use and increases grower profitability, which should lead to related reductions in carbon emissions and nutrient runoff, resulting in environmental benefits. How many potential environmental benefits will be realized will depend largely on how widely WSN-based irrigation management is adopted, and how much the adopted systems reduce water and energy use and air and water emissions in the operations where they are adopted. Extrapolating from the results reported in this issue, Majsztrik et al. (2013b) conservatively estimate that adoption by half of existing U.S. ornamental operations could save enough water to supply over 400,000 households, cut greenhouse gas emissions by the equivalent of 7500 cars, and lower nitrogen runoff by 300-600 Mg.

Project results that indicate potentially high economic returns to ornamental growers from investing in WSN-based irrigation management systems are just starting to be published, and the systems are just becoming commercially available for ornamental growers. So we stand at the threshold of the adoption/diffusion curve that will determine how quickly and how widespread the environmental and economic benefits from these systems will be realized
(Majsztrik et al., 2013b). Results of a national survey of ornamental growers indicate that adoption may be rapid and widespread. Growers report overwhelmingly positive views of WSNs and look forward to increased irrigation efficiency, improved product quality, reduced product losses, reduced irrigation management costs, reduced disease prevalence, increased ability to manage growth, and reduced monitoring costs. System cost and reliability are major concerns, indicating that making WSNs affordable and robust will likely be critical determinants of the speed and breadth of adoption (Majsztrik et al., 2013a).

Support Issues. The maintenance and calibration of sensors and equipment is an ongoing concern, particularly for growers who may be uncomfortable with the technology and equipment. We see an opportunity for consultants to maintain and remotely monitor WSNs to maximize performance. As part of our project, we are developing an online knowledge center, to provide assistance and guidance about various aspects of WSN deployment, sensor use, strategies, and best practices (Lea-Cox and Monahan, 2012). In the future, we need to continue to improve and further integrate data analysis tools for handling and visualizing the large volumes of data from sensor networks. Predictive models for plant water use and environmental and disease management tools are being developed for growers, but we need to optimize and verify these models for varying scales and in different environments.

\section{Conclusions}

We have successfully developed the hardware and software needed to deploy WSNs in greenhouses and nurseries and collaborated with growers to assure that these networks meet the needs of growers. Our scientific and engineering work has helped growers to develop improved irrigation strategies, which have been implemented using the WSNs. On-farm trials have allowed us to quantify the economic benefits of these WSNs, while extrapolations from the on-farm trials have allowed us to estimate public benefits. Feedback from our grower collaborators has been unanimously positive and an industry-wide survey has shown extensive interest in WSNs, 
suggesting that adoption may be rapid and widespread.

\section{Literature cited}

Agarwal, A. M.S. delos Angeles, R. Bhatia, I. Cheret, S. Davila-Poblete, M. Falkenmark, F. Gonzalez Villarreal, T. Jønch-Clausen, M.A. Kadi, J. Kindler, J. Rees, P. Roberts, P. Rogers, M. Solanes, and A. Wright. 2000. Integrated water resources management. Global Water Partnership, Stockholm, Sweden.

Akyildiz, I.F., W. Su, Y. Sankarasubramaniam, and E. Cayirci. 2002. Wireless sensor networks: A survey. Comput. Netw. 38:393422 .

Allen, R.G., L.S. Pereira, D. Raes, and M. Smith. 1989. Crop evapotranspiration: Guidelines for computing crop water requirements. FAO Irr. Drainage Paper No. 56. 30 Oct. 2013. <http://www.fao.org/ docrep/x0490e/x0490e00.htm>.

Arndt, D.S., M.O. Baringer, and M.R. Johnson. 2013. 2010: State of the climate in 2009. Bull. Amer. Meteorol. Soc. 91:S1-S222. <http://journals.ametsoc. org/doi/pdf/10.1175/BAMS-91-7StateoftheClimate>.

Bacci, L., P. Battista, and B. Rapi. 2008. An integrated method for irrigation scheduling of potted plants. Sci. Hort. 116:89-97.

Balendonck, J., C. Stanghellini, J. Hemming, F.L.K. Kempkes, and B.A.J. van Tuijl. 2009. Farm level optimal water management: Assistant for irrigation under deficit (FLOW-AID). Acta Hort. 807:247252.

Ball, J.T., I.E. Woodrow, and J.A. Berry. 1987. A model predicting stomatal conductance and its contribution to the control of photosynthesis under different environmental conditions, p. 221-224. In: J. Biggins (ed.). Progress in photosynthesis research. Martinus Nijhoff Publishers, Dordrecht, The Netherlands.

Barnard, D.M. and W.L. Bauerle. 2013. The implications of minimum stomatal conductance on modeling water flux in forest canopies. J. Geophys. Res. Biogeosci. 118:1322-1333.

Bauerle, T.L., W.L. Bauerle, M. Goebel, and D.M. Barnard. 2013a. Root system distribution influences substrate moisture measurements in containerized ornamental tree species. HortTechnology 23:754759.

Bauerle, W.L., A.B. Daniels, and D.M. Barnard. 2013b. Carbon and water flux responses to physiology by environment interactions: A sensitivity analysis of variation in climate on photosynthetic and stomatal parameters. Clim. Dyn., doi: 10.1007/s00382-013-1894-6.

Bauerle, W.L., C.J. Post, M.E. McLeod, J.B. Dudley, and J.E. Toler. 2002. Measurement and modeling of the transpiration of a temperate red maple container nursery. Agr. For. Meteorol. 114:45-57.

Bauerle, W.L., J.D. Bowden, M.F. McLeod, and J.E. Toler. 2004. Modeling intracrown and intracanopy interactions in red maple: Assessment of light transfer on carbon dioxide and water vapor $\mathrm{ex}$ change. Tree Physiol. 24:589-597.

Bauerle, W.L. and J.D. Bowden. 2011 a. Separating foliar physiology from morphology reveals the relative roles of vertically structured transpiration factors within red maple crowns and limitations of larger scale models. J. Expt. Bot. 62:4295-4307.

Bauerle, W.L. and J.D. Bowden. $2011 \mathrm{~b}$. Predicting transpiration response to climate change: Insights on physiological and morphological interactions that modulate water exchange from leaves to canopies. HortScience 46:163-166.

Bauerle, W.L., R. Oren, D.A. Way, S.S. Qian, P.C. Stoy, P.E. Thornton, J.D. Bowden, F.M. Hoffman, and R.F. Reynolds. 2012. Photoperiodic regulation of the seasonal pattern of photosynthetic capacity and the implications for carbon cycling. Proc. Natl. Acad. Sci. USA 109:86128617

Beeson, R.C. 2012. Development of a simple reference evapotranspiration model for irrigation of woody ornamentals. HortScience 47:264-268.

Belayneh, B.E., J.D. Lea-Cox, and E. Lichtenberg. 2013. Costs and benefits of implementing sensor-controlled irrigation in a commercial pot-in-pot container nursery. HortTechnology 23 : 760-769.

Bitelli, M. 2011. Measuring soil water content: A review. HortTechnology 21:293-300.

Bowden, J.D. and W.L. Bauerle. 2008. Measuring and modeling the variation in species-specific transpiration in temperate deciduous hardwoods. Tree Physiol. 28:1675-1683.

Bowden, J.D., W.L. Bauerle, J.D. LeaCox, and G.F. Kantor. 2005. Irrigation scheduling: An overview of the potential to integrate modeling and sensing techniques in a windows-based environment. Proc. Southern Nursery Assn. Res. Conf. 50:577-579.

Burnett, S.E. and M.W. van Iersel. 2008. Morphology and irrigation efficiency of Gaura lindheimeri grown with capacitance- sensor controlled irrigation. HortScience 43:1555-1560.

Chappell, M., S.K. Dove, M.W. van Iersel, P.A. Thomas, and J. Ruter. 2013. Implementation of wireless sensor networks for irrigation control in three container nurseries. HortTechnology 23:747-753.

Cifre, J., J. Bota, J.M. Escalona, H. Medrano, and J. Flexas. 2005. Physiological tools for irrigation scheduling in grapevine (Vitis vinifera L.). Agr. Ecosyst. Environ. 106:159-170.

Dane, J.H. and G.C. Topp. 2002. Methods of soil analysis. Part 4: Physical methods. Soil Sci. Soc. Amer., Madison, WI.

Fereres, E., D.A. Goldhamer, and L.R. Parsons. 2003. Irrigation water management of horticultural crops. HortScience 38:1036-1042.

Fry, A. 2005. Facts and trends, water. World Business Council for Sustainable Development/Earthprint, Stevanage, England.

Hansen, R.C. and C. Pasian. 1999. Using tensiometers for precision microirrigation of container-grown roses. Appl. Eng. Agr. $15: 483-490$.

Hutson, S.S., N.L. Barber, J.F. Kenny, K.S. Linsey, D.S. Lumia, and M.A. Maupin. 2004. Estimated use of water in the United States in 2000U.S. Dept. Interior. U.S. Geol. Surv. Circ. 1268.

Jones, H.G. 2004. Irrigation scheduling: Advantages and pitfalls of plant-based methods. J. Expt. Bot. 55:2427-2436.

Jones, H.G. 2008. Irrigation scheduling: Comparison of soil, plant and atmosphere monitoring approaches. Acta Hort. 792:391-403.

Kenny, J.F., N.L. Barber, S.S. Hutson, K.S. Linsey, J.K. Lovelace, and M.A. Maupin. 2009. Estimated water use in the United States in 2005U.S. Dept. Interior. U.S. Geol. Surv. Circ. 1344.

Kim, J. and M.W. van Iersel. 2009. Daily water use of abutilon and lantana at various substrate water contents. Proc. Southern Nursery Assn. Res. Conf. 54:12-16.

Kim, J., M.W. van Iersel, and S.E. Burnett. 2011. Estimating daily water use of two petunia cultivars based on plant and environmental factors. HortScience 46:12871293.

Kohanbash, D., A. Valada, and G.F. Kantor. 2011. Wireless sensor networks and actionable modeling for intelligent irrigation. Amer. Soc. Agr. Biol. Eng. Paper No. 1111174.

Kohanbash, D., G. Kantor, T. Martin, and L. Crawford. 2013. Wireless sensor 
network design for monitoring and irrigation control: User-centric hardware and software development. HortTechnology 23:725-734

Lea-Cox, J.D. 2012. Using wireless sensor networks for precision irrigation scheduling, p. 233-258. In: M. Kumar (ed.). Problems, perspectives and challenges of agricultural water management. 27 Sept. 2013. <http://www. intechopen.com/books/problemsperspectives-and-challenges-of-agriculturalwater-management $>$.

Lea-Cox, J.D., A.G. Ristvey, F.R. ArguedasRodriguez, D.S. Ross, J. Anhalt, and G.F. Kantor. 2008. A low-cost multihop wireless sensor network, enabling real-time management of environmental data for the greenhouse and nursery industry. Acta Hort. 801:523-529.

Lea-Cox, J.D., F.R. Arguedas-Rodriguez, P.Amador, G. Quesada, and C.H. Mendez. 2006. Management of the water status of a gravel substrate by ech 20 probes to reduce rbizopus incidence in the container production of Kalanchoe blossfeldiana. Proc. Southern Nursery Assn. Res. Conf. 51:511-517.

Lea-Cox, J.D., G.F. Kantor, W.L. Bauerle, M.W. van Iersel, C. Campbell, T.L. Bauerle, D.S. Ross, A.G. Ristvey, D. Parker, D.M. King, R. Bauer, S.M. Cohan, P.A. Thomas, J.M. Ruter, M. Chappell, M. Lefsky, S. Kampf, and L. Bissey. 2010. A specialty crops research project: Using wireless sensor networks and crop modeling for precision irrigation and nutrient management in nursery, greenhouse and green roof systems. Proc. Southern Nursery Assn. Res. Conf. 55:211-215.

Lea-Cox, J.D. and L. Monahan. 2012. Smart-farms knowledge center. 27 Sept. 2013. <http://www.smart-farms.org>.

Lichtenberg, E., J. Majsztrik, and M. Saavoss. 2013. Profitability of sensorbased irrigation in greenhouse and nursery crops. HortTechnology 23:770-774.

Lieth, J.H. and D.W. Burger. 1989. Growth of chrysanthemum using an irrigation system controlled by soil moisture tension. J. Amer. Soc. Hort. Sci. 114:387392.

Majsztrik, J.C., A.G. Ristvey, and J.D. Lea-Cox. 2011. Water and nutrient management in the production of containergrown ornamentals. Hort. Rev. 38: 253-296.

Majsztrik, J.C., E. Lichtenberg, and M. Saavoss. 2013a. Ornamental grower perceptions of wireless irrigation sensor networks: Results from a national survey. HortTechnology 23:775-782.
Majsztrik, J.C., E.W. Price, and D.M. King. 2013b. Environmental benefits of wireless sensor-based irrigation networks: Case-study projections and potential adoption rates. HortTechnology 23:783-793.

McCullogh, J., P. McCarthy, S.M. Guru, W. Peng, D. Hugo, and A. Terhorst. 2008. Wireless sensor network deployment for water use efficiency in irrigation. Proc. Wkshp. Real-World Wireless Sensor Networks, Glasgow, Scotland. p. 46-50.

Nemali, K.S. and M.W. van Iersel. 2006. An automated system for controlling drought stress and irrigation in potted plants. Sci. Hort. 110:292-297.

Pardossi, A., L. Incrocci, G. Incrocci, F. Malorgio, P. Battista, L. Bacci, B. Rapi, P. Marzialetti, J. Hemming, and J. Balendonck. 2009. Root zone sensors for irrigation management in intensive agriculture. Sensors (Basel Switzerland) 9:2809-2835.

Raviv, M., J.H. Lieth, and R. Wallach. 2000. Effect of root-zone physical properties of coir and UC mix on performance of cut rose (cv. Kardinal). Acta Hort. 554:231-238.

Reynolds, R.F., W.L. Bauerle, and Y. Wang. 2009. Simulating carbon dioxide exchange rates of deciduous tree species: Evidence for a general pattern in biochemical changes and water stress re sponse. Ann. Bot. (Lond.) 104:775-784.

Ristvey, A.G., J.D. Lea-Cox, and D.S. Ross. 2004. Nutrient uptake, partitioning and leaching losses from containernursery production systems. Acta Hort. 630:321-328.

Ross, D.S., J.D. Lea-Cox, and K.M. Teffeau. 2001. The importance of water in the nutrient management process. Proc. Southern Nursery Assn. Res. Conf. 46:588-591.

Secchi, S., P.W. Gassman, M. Jha, L. Kurkalova, H.H. Feng, T. Campbell, and C.L. King. 2007. The cost of cleaner water: Assessing agricultural pollution reduction at the watershed scale. J. Soil Water Conserv. 62:10-22.

Shani, U., Y. Tsur, A. Zemel, and D. Zilberman. 2009. Irrigation production functions with water-capital substitution. Agr. Econ. 40:55-66.

Smajstrla, A.G. and D.S. Harrison. 1998. Tensiometers for soil moisture measurement and irrigation scheduling. Univ. Florida Inst. Food Agr. Serv. Ext. Circ. 487.

Smith, K.A. and C. Mullins. 2001. Soil and environmental analysis: Physical methods. 2nd ed. Marcel Decker, New York, NY.
Starry, O. 2013. The comparative effects of three Sedum species on green roof stormwater retention. PhD Diss., Univ. Maryland, College Park.

Topp, G.C. 1985. Time-domain reflectometry (TDR) and its application to irrigation scheduling. Adv. Irr. 3:107-127.

U.S. Agency for International Development. 2013. Growing more with less: Feed the future and water. United States global hunger and food security initiative. 8 Oct. 2013. <http://feedthefuture. gov/article/growing-more-less-feedfuture-and-water $>$.

U.S. Department of Agriculture. 2004. The 2002 Census of agriculture. U.S. Dept. Agr., Natl. Agr. Stat. Serv., Washington, DC.

U.S. Department of Agriculture. 2009. The 2007 Census of agriculture. U.S. Dept. Agr., Natl. Agr. Stat. Serv., Washington, DC.

van Iersel, M.W., M. Chappell, and J.D. Lea-Cox. 2013. Sensors for improved efficiency of irrigation in greenhouse and nursery production. Hort Technology 23:735-746.

van Iersel, M.W., R.M. Seymour, M. Chappell, F. Watson, and S.K. Dove. 2009. Soil moisture sensor-based irrigation reduces water use and nutrient leaching in a commercial nursery. Proc. Southern Nursery Assn. Res. Conf. 54:17-21.

van Iersel, M.W., S.K. Dove, J.-G. Kang, and S.E. Burnett. 2010. Growth and water use of petunia as affected by substrate water content and daily light integral. HortScience 45:277-282.

van Iersel, M.W., S.K. Dove, and S.E. Burnett. 2011. The use of soil moisture probes for improved uniformity and irrigation control in greenhouses. Acta Hort. 893:1049-1056.

Wang, Y.P. and P.G. Jarvis. 1990. Description and validation of an array model-MAESTRO. Agr. For. Meteorol. 51:257-280.

Warsaw, A.L., R.T. Fernandez, B.M. Cregg, and J.A. Andresen. 2009. Water conservation, growth, and water use efficiency of container-grown woody ornamentals irrigated based on daily water use. HortScience 44:1308-1318.

Yeager, T.H., T.E. Bilderback, D. Fare, C. Gilliam, J.D. Lea-Cox, A.X. Niemiera, J.M. Ruter, K. Tilt, S.L. Warren, T. Whitwell, and R.D. Wright. 2007. Best management practices: Guide for producing nursery crops. 2nd ed. Southern Nursery Assn., Atlanta, GA. 